\title{
Computational Studies on Photovoltaic Devices
}

\author{
B. Madhuri \\ M.tech Student \\ Dept. of Instrument technology, \\ AU College of Engineering (A) \\ Andhra University, Visakhapatnam, \\ Andhra Pradesh, India
}

\author{
P. Swapna \\ Assistant professor \\ Dept. of Instrument technology \\ AU College of Engineering $(A)$ \\ Andhra University, Visakhapatnam \\ Andhra Pradesh, India.
}

\begin{abstract}
The energy demand is growing rapidly and thus the need for a renewable source that will not pollute the environment is of prime importance. Some projections state that by 2050 the energy demand will be around 13 terawatts (TW). Yet majority of the energy requirements are satisfied by fossil fuels where as the use of renewable energy resources could help in meeting the energy demands and also in reducing the pollution. Solar energy is one of the most readily available renewable energy resources. The solar energy is non pollutant and maintenance free. Photovoltaic (PV) is a method of generating electrical power by converting solar radiation into direct current electricity using semiconductors that exhibit the photovoltaic effect. To reduce the manufacturing cost of the solar panel, $\mathrm{I}-\mathrm{V}$ and $\mathrm{P}-\mathrm{V}$ characteristics and various parameters that affect the solar panel should be customized before the fabrication of solar panel. Here, MATLAB software tool is used to simulate the characteristics (I-V \& PV) of solar panel. The main objective of this work is to study the influence of the irradiance, the ambient temperature and the no of series and parallel cells that are onnected in the panel to achieve the global efficiency.
\end{abstract}

The overall performance of solar cell varies with varying Irradiance, Temperature and no of series and parallel cells that are connected in solar panel. With the change in the time of the day the irradiance received from the sun by the PV panel changes. Not only irradiance, temperature also changes. Due to the change in the temperature, the current density changes hence there is a change in efficiency as well as Fill factor. There another factor that affecting the solar panel efficiency is the no of series and parallel cells that are connected in the solar panel.

\section{Keywords:}

Efficiency, Fill Factor, Irradiance, no of series Solar cells, no of parallel solar cells, Temperature, Photovoltaic Device.

\section{INTRODUCTION}

Energy exists freely in nature. Researchers from different parts of the world have reported that, to meet the $13 \mathrm{TW}$ energy crisis, we need to grow the renewable energy industry very rapidly ( 35\% per year) (McGehee, 2009). There are two kinds of energy sources such as renewable energy sources and non renewable energy sources. Carbon based energy resources are termed as Non-renewable sources of energy. The non renewable energy sources such as oil will be available only for 40 years, gas for 50 years and coal will only for 200 years (Li B et al, 2006). Renewable energy sources do not emit any kind of greenhouse gases that pollute the atmosphere as compared to non renewable sources. Renewable energy sources such as solar, biomass, geothermal, hydroelectric and wind power generation have emerged as potential alternatives. As opposed to fossil fuels, which draw on finite resources that may eventually become too expensive to retrieve, renewable energy sources are generally unlimited in availability. The solar electricity is growing rapidly but is a relatively expensive form of renewable energy. Solar PV cells are electronic devices that use $\mathrm{P}-\mathrm{N}$ junctions to directly convert sunlight into electrical power using photovoltaic principle (A. E. Becquerel, 1939). A PV cell basic voltage is in the range of 0.5 to $0.8 \mathrm{~V}$ which is not sufficient for commercial use. The solar cells connected in the form of module can give the voltage at least to charge a standard battery of $12 \mathrm{~V}$. Whereas a decade ago only "conventional" crystalline (Green. M.A et $\mathrm{al}, 2001$ ) and amorphous Si technologies (Guha S et al, 2000) were commercially available for terrestrial installations, the massive growth of the photovoltaic (PV) market worldwide is nowadays accompanied by a large number of novel technologies and concepts entering the market. Among them is the thin film (TF) technology which is widely used now (Bergman R.B et al, 2002). To experiment with PV cells in the laboratory is time consuming and costly task. So, to overcome this problem, simulation techniques are used to simulate the behavior of PV cells under different conditions. The efficiency of solar cell/module/array varies due to changes in various factors such as temperature, irradiance and no of solar cells connected in series and parallel. Not only efficiency, other parameters such as Fill factor, short circuit current and open circuit voltage etc. also change.

\section{CHARACTERISTICS OF PHOTOVOLTAIC DEVICES}

$\mathrm{I}-\mathrm{V}$ and $\mathrm{P}-\mathrm{V}$ curves are used to compare the performance of PV / Solar Modules. The typical I-V and P-V curves of PV modules are in fact usually rated at Standard Test Conditions $1000 \mathrm{~W} / \mathrm{m} 2, \mathrm{AM} 1.5 ; \mathrm{T}=25^{\circ} \mathrm{C}$ are shown in the Figure 1 . The power available from a photovoltaic device at any point along the curve is just the product of Current (I) in Amps (A) and Voltage (V) in Volts (V) at that point and is expressed in Watts. At the short circuit current point, the power output is zero, since the voltage is zero. At the open circuit voltage point, the power output is also zero, but this time it is because the current is zero.

A Solar (PV) Cell/ Panel / Module produces its maximum current when there is a short circuit between its Positive and Negative terminals. This maximum current is known as the Short Circuit Current (ISC). Conversely, the maximum voltage occurs when there is a break in the circuit. This is called the Open Circuit Voltage (Voc). The efficiency is the ratio of the electrical output of a solar cell to the incident energy in the form of sunlight and it is the most commonly used parameter to compare the performance of one solar cell to another. The efficiency depends on various factors such as the intensity of the incident sunlight, temperature and no of series and parallel cells connected in a panel. 


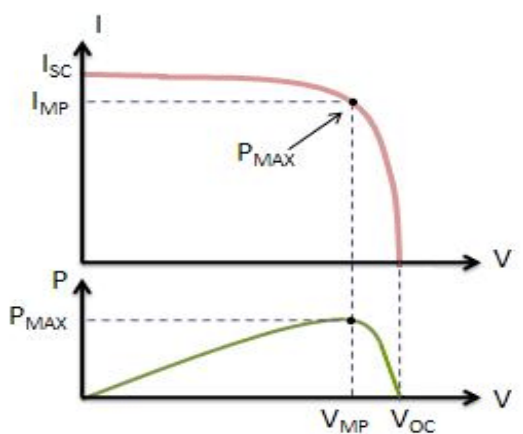

Figure: 1 Typical I-V curve and P-V curve under STC

\section{EFFECT OF VARIOUS FACTORS ON CHARACTERISTICS OF SOLAR PANEL}

The efficiency of the PV system depends on several climatic factors such as the solar radiation, the ambient temperature and the no of series and parallel solar cells of solar panels. One of the key factors impacting the amount of electricity produced by the solar panels is the temperature at which they operate. As the solar panel gets hotter, it will produce less power from the same amount of sunlight. The electrons have more energy at rest position when solar panel is hotter. The voltage is the difference between the rest energy and excited energy hence at this conditions the difference is low means as temperature increases the band gap reduces. A large band gap will make it more difficult for a carrier to be thermally excited across the band gap. Hence more carriers excite from valance band to conduction band when the band gap reduces and voltage value decreases (Martina Calais et al, 2000, Pradhan Arjyadhara et al, 2013) and there is marginal change in current. Solar panel output current is directly proportional to solar intensity. When the irradiance level of light increases, the number of photons and energy entering the PV device increases, and the number of electrons released transferring to electrical energy also increases. Changes in irradiance significantly affect output current, but have a much smaller affect on voltage. The current is directly proportional to light intensity, and the voltage varies more slowly (Surya Kumari. J et al, 2012). When the number of solar cells in the panel connected in series changes the voltage changes and the current remains constant. When the no of solar cells connected in parallel changes the current value changes and voltage remains constant.

\section{RESULT AND ANALYSIS}

$\mathrm{I}-\mathrm{V}$ and $\mathrm{P}-\mathrm{V}$ characteristics of solar module by varying the irradiance from 200 to $1000 \mathrm{~W} / \mathrm{m}^{2}$ and temperature from 25 to 450C are shown in Figures from 2 to 4 under the standard test conditions. The observations are tabulated in Table 1 .

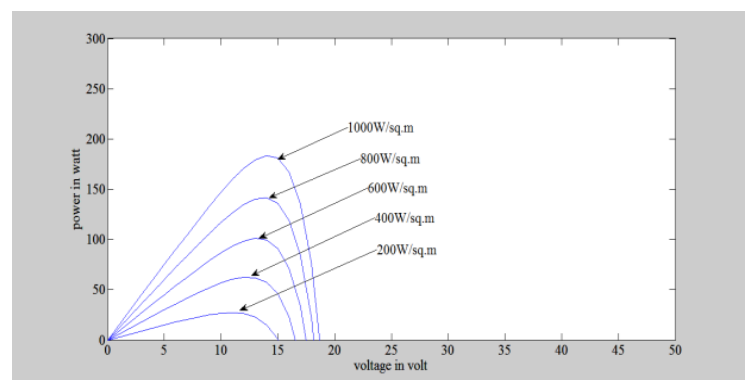

Figure: $2 \mathrm{I}-\mathrm{V}$ and P-V curves at temperature 250C.
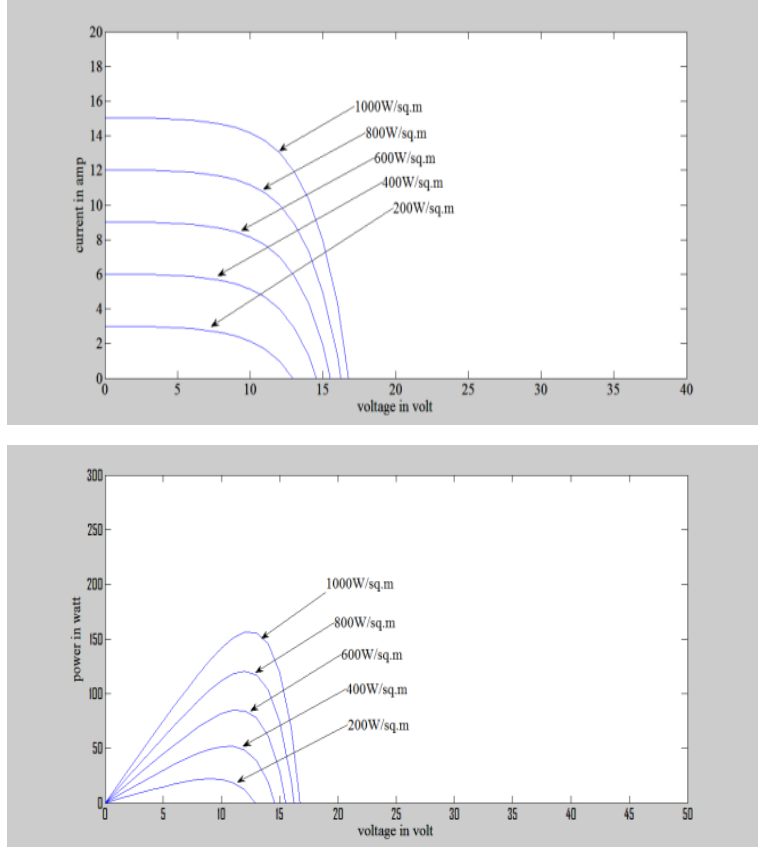

Figure: $3 \mathrm{I}-\mathrm{V}$ and $\mathrm{P}-\mathrm{V}$ curves at temperature $350 \mathrm{C}$.
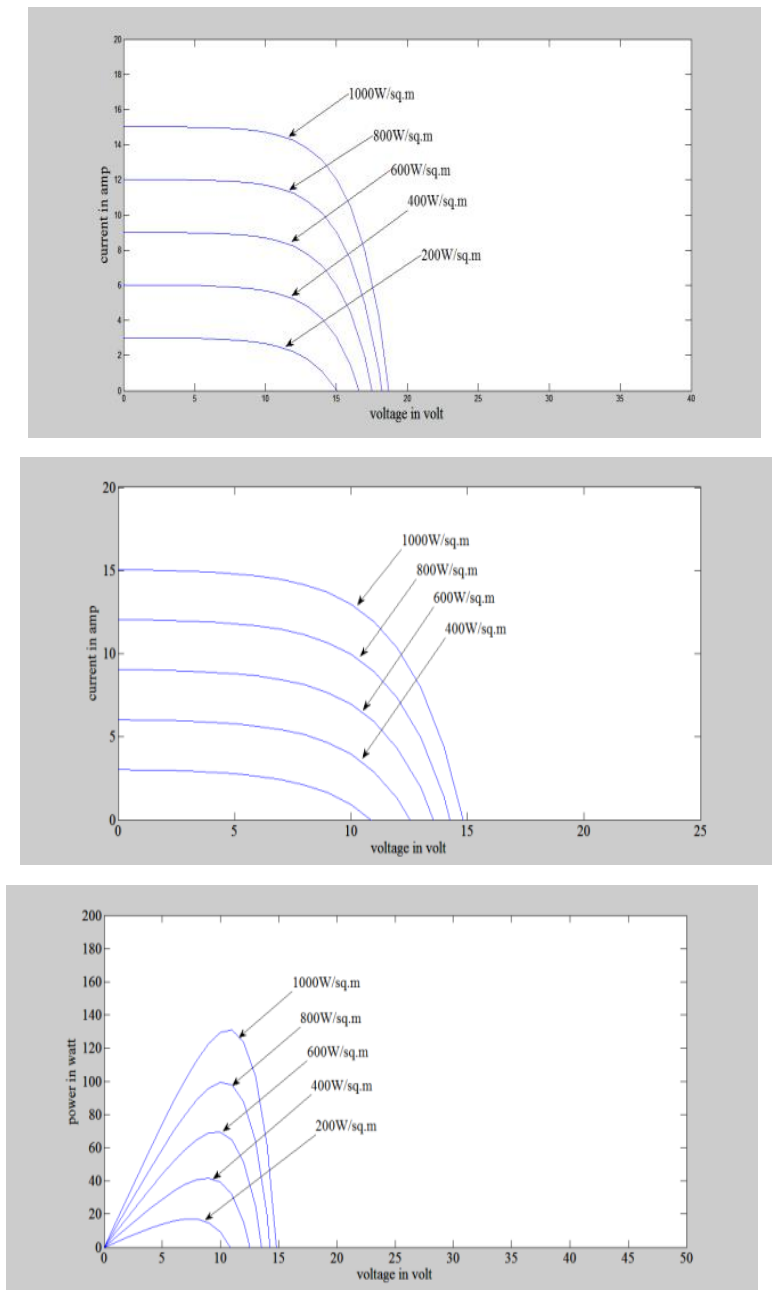

Figure: $4 \mathrm{I}-\mathrm{V}$ and $\mathrm{P}-\mathrm{V}$ curves at temperature $450 \mathrm{C}$.

$\mathrm{I}-\mathrm{V}$ and $\mathrm{P}-\mathrm{V}$ characteristics of solar module by varying the no of solar cells connected in series and no of cells connected in 
parallel are shown in Figures 5 and 6 under the standard test conditions and observations are tabulated in Table 2.
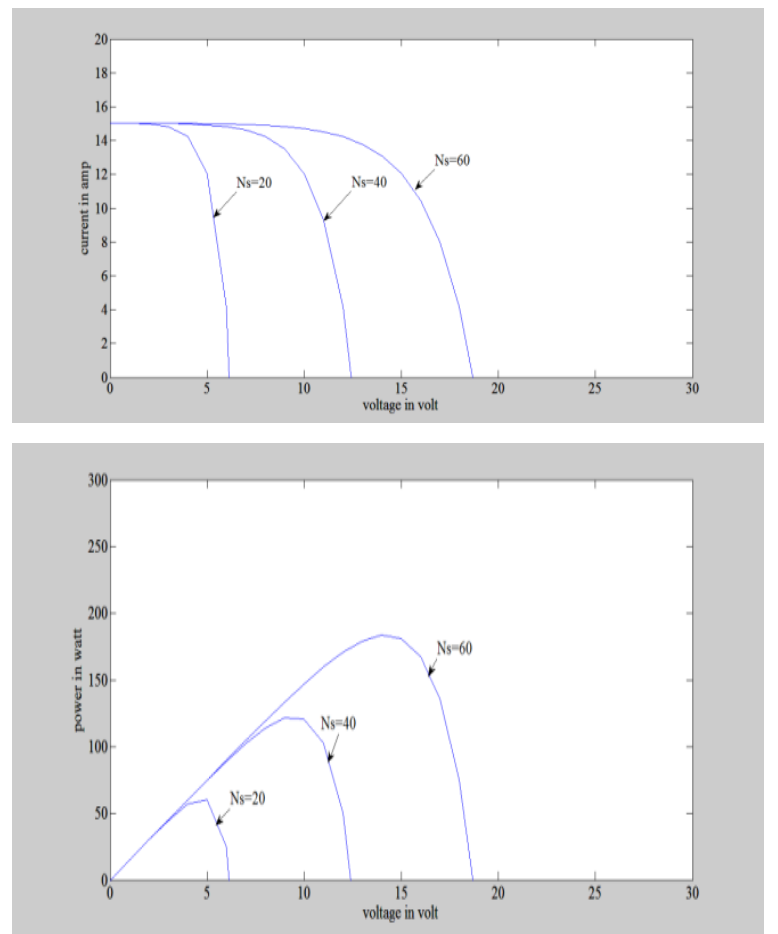

Figure 5: I-V and P-V curves by varying the series no of cells connected in panel

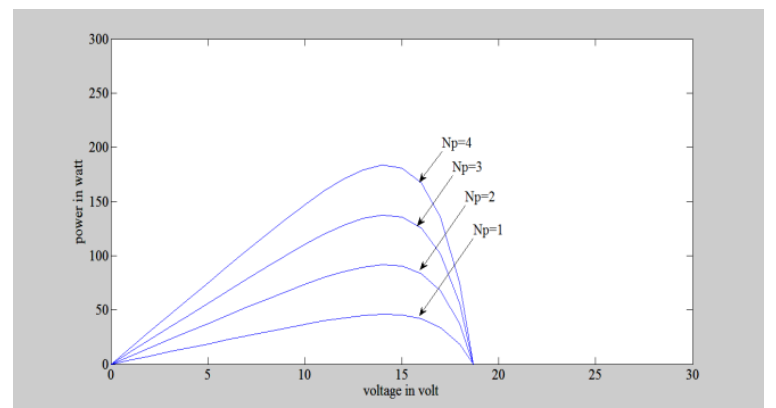

Figure: $6 \mathrm{P}-\mathrm{V}$ curves by varying the parallel no of solar cells

\section{COMPARATIVE STUDY OF SOLAR PANEL WITH RESPECT TO EFFICIENCY}

As the temperature increases, the open-circuit voltage decreases, thereby decreasing the fill factor and finally decreasing the efficiency of a solar cell. The efficiencies are taken at various temperatures under standard test conditions (STC) and the observations are tabulated in the Table 1.

Table 1: Efficiencies at various temperatures

\begin{tabular}{|l|l|l|}
\hline SL NO & Temperature $\left({ }^{\circ} \mathrm{C}\right)$ & Efficiency (\%) \\
\hline 1 & 25 & 18.35 \\
\hline 2 & 28 & 17.51 \\
\hline 3 & 30 & 16.99 \\
\hline 4 & 33 & 16.21 \\
\hline
\end{tabular}

\begin{tabular}{|l|l|l|}
\hline 5 & 35 & 15.64 \\
\hline 6 & 40 & 14.32 \\
\hline 7 & 45 & 13.01 \\
\hline
\end{tabular}

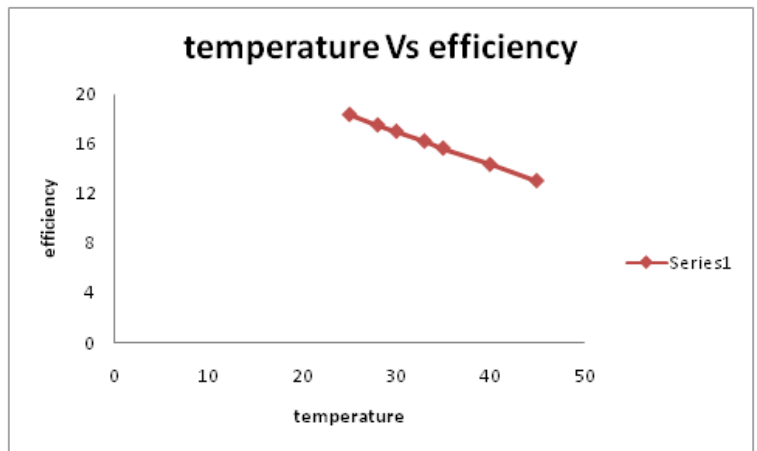

Figure 7: Temperature Vs Efficiency

The efficiency is the most commonly used parameter to compare the performance of one solar cell to another. From the figure 7 , the efficiency ( 18.35 to $13.01 \%$ ) of the module decreases by varying the temperature from 25 to $45^{\circ} \mathrm{C}$. There is a drastic decrease in efficiency after the temperature $40^{\circ} \mathrm{C}$. It concludes that efficiency decreases by increasing the temperature.

\section{CONCLUSION}

This paper deals with the modeling and simulation of solar array in MATLAB environment and obtained I-V and P-V curves from the photovoltaic array. It concludes that, increase in temperature increases the rate of photon generation rapidly. This results reduction in band gap and leads to marginal changes in current but major changes in voltage. Similarly, changes in irradiance significantly affect output current, but less effect on voltage. Therefore, voltage varies more slowly as the current is directly proportional to light intensity. The voltage increases with increase the no of solar cells connected in series and vice versa and there is no change in current. The current increases with increase the no of parallel connection of solar cells and there is no change in voltage. Finally, it concludes that modeling and simulation is essential before fabrication of photovoltaic array which reduces the cost of manufacturing.

\section{REFERENCES}

[1] Becquerel A.E, C. R. Acad(1839). Sci. Paris, 9, 561.

[2] Bergmann R.B and Werner J.H (2002) The Future of Crystalline Si thin Films on Foreign Substrate", Thin Solid Films, Vol. 403-404, pp 162.

[3] Chetan Sing Solanki (2012) Solar Photovoltaics: Fundamentals, Technologies and Applications.

[4] Chopra. K.L, Paulson. P.D and Dutta. V (2004) Thin Flim Solar cells. Progress in Photovoltaics Research and Applications, Vol. 12, p. 69.

[5] Cindy Hill (2014). The Effect of Temperature on Solar Pnel Power Production. Homeguides Web http://homeguides.sfgate.com/effects-Temperature-SolarPanel-power-production-79764.html. Accessed 2014. 
[6] Green M.A, Zhao J, Wand A and Wenham S.R (2001) Progress and outlook of Efficiency Crystalline Si Solar Cells. Solar Energy Materials and Solar Cells, Vol.65, p.9.

[7] Guha S, Yang J and Banerjee A (2000) Amporphous Si Alloy Photovoltaic Research- Present and Future", Progress in Photovoltaic Research and Applications, Vol.8, p.141.

[8] Kamat, P.V (2007) Journal of Physical chemistry C,111, pp 2834-2860.

[9] Li B, Wang L, Kang B, Wang P and Qiu Y (2006) Solar Energy Materials and Solar cells,90, pp549-573,

[10] Martina Calais, Vassillios G.Agelidis (2000) A Transformer less Five Level Cascaded Inverter Based Single -Phase Photovoltaic System. Centre of Renewable Power deliver, University of Glasgow, U.K.

[11] Maycock, P (2003) PV Market Update. Renewable Energy World, Vol. 6(4), p.8.

[12] Pradhan Arjyadhara, Ali S.M, Jena Chitralekha (2013) Analysis of Solar PV cell Performance with Changing
Irradiance and Temperature International Journal Of Engineering And Computer Science ISSN:2319-7242 Volume 2 Issue 1 Page No. 214-220.

[13] Ramos Hernanz JA, Campayo Matrin JJ, Zamora Belver I, Larranaga Lesaka J, Zulueta Guerrero E and Puelles Perez E (2010) Modelling of Photovoltaic Module. International Conference on Renewable Energies and Power Quality (ICREPQ’ 10) Granada (Spain).

[14] Sonal Panwar, Saini R.P (2012) Development and Simulation of Solar Photovoltaic Model using Matlab/Simulink and its parameter extraction. International Conference on Computing and Control Engineering, Published by Coimbatore Institute of Information Technology, ISBN 978-1-4675-2248-9.

[15] Surya Kumari. J and Sai Babu.Ch (2012) Mathematical Modeling and Simulation of Photovoltaic Cell using Matlab-Simulink Environment. International Journal of Electrical and Computer Engineering (IJECE) Vol. 2, No. 1, pp. 26-34. 